\title{
ASPECTOS DE INTERESSE ATUAL DO MATRIMÔNIO ROMANO
}

\author{
Dárcio Roberto Martins Rodrigues \\ Professor Doutor do Departamento de Direito Civil da \\ Faculdade de Direito da Universidade de São Paulo
}

\begin{abstract}
Resumo:
Neste artigo se contemplam em linhas gerais os aspectos mais importantes do casamento romano que, em cotejo com o atual Direito Civil, ainda oferecem ensejo à reflexão. Em particular, discute-se se no Direito Romano a coabitação fazia parte dos deveres conjugais, ou ainda se é possivel falar de um direito dos cônjuges à coabitação.
\end{abstract}

Abstract:

In this essay, the most important aspects of the roman marriage are contemplated in general lines, in comparison to the present-day Civil Right, still offers us the opportunity of reflection. As particular matter, it's discussed whether in the Roman Right the cohabitation was part of the conjugal duty, or still, if it's possible to speak about a consort right to cohabitation.

Unitermos: casamento romano; coabitação; direito dos cônjuges.

\section{I - Introdução}

A família, como instituição social basilar, afigura-se sempre, em praticamente qualquer civilização, comó elemento fundamental da organização da vida em sociedade. Por esse motivo, não há ordenamento jurídico que não tenha como uma de suas colunas mestras o Direito de Família, sempre consolidado nos costumes mais antigos e nas tradições mais arraigadas na consciência dos povos.

Isso não significa, entretanto, que o conceito de família seja o mesmo em qualquer ordem jurídica. Ao contrário, o que se verifica é que, precisamente em razão desse seu vínculo essencial com os costumes e valores de cada sociedade, o Direito de Família é o que maiores variações apresenta em função do tempo e do lugar onde vigora.

A família romana, nos contornos em que era concebida pelos antigos quirites, em nada se assemelha à família de nossos dias, de que trata o Direito Civil 
moderno. Destarte, é dificultoso e até arriscado intentar estudos de direito comparado entre elas, como se se tratasse de um mesmo instituto, à guisa do que se faz, por exemplo, com o direito de propriedade ou os contratos.

Destes, sim, se pode dizer que, embora revestidos de todas as peculiaridades com que a finura da doutrina moderna e os reclamos práticos da sociedade contemporânea os recobriram, são herdeiros diretos de seus equivalentes romanos. Sofreram, por certo, transformações e desdobramentos que em muito os distanciaram das concepções originais romanas, mas neles ainda se reconhecem, com toda clareza, as mesmas características primevas que lhes dão identidade como institutos jurídicos. Há, podemos dizer, uma continuidade histórica inegável desde Roma até hoje, e a sabedoria dos jurisconsultos clássicos quase sempre pode aplicarse, de modo imediato, para a compreensão de muitos problemas que nos oferece o direito privado moderno.

Com a família, no entanto, tal não ocorre de modo tão simples. Não houve uma mera evolução de institutos, mas uma completa reformulação de conceitos e valores. A família proprio iure romana difere da nossa em sua própria estrutura imanente, e nas relações internas que a sustentam. Antes, portanto, de pretender extrair qualquer ilação do estudo histórico de institutos pertencentes ao direito de família (no presente caso, o matrimônio), cumpre buscar a compreensão das diferenças entre essas estruturas, a fim de que se possa melhor sopesar a influência que esta ou aquela concepção romana ainda possa exercer sobre o pensar do jurista moderno.

Assim sendo, neste nosso estudo não pretendemos examinar o casamento romano tal como este se apresenta nos manuais didáticos, ou seja, na completa exposição sistemática de seus contornos jurídicos e sociais. Um semelhante escopo seria por demais pretensioso para um trabalho de limitada extensão como o presente, e acarretaria o risco de resultar em uma exposição superficial ou meramente repetitiva. Nossa atenção será voltada, antes, para a análise mais detida de alguns pontos ou aspectos fundamentais desse instituto, buscando uma melhor compreensão da sua natureza originária (em Roma) em confronto com a realidade de nossos dias. Na consciência de que todo estudo histórico-jurídico só faz sentido e tem razão de ser se estiver inserido numa visão prevalentemente jurídico-dogmática (e não meramente histórica, o que transformaria o Direito Romano em simples peça de museu ou antiquário), cuidamos de voltar nossa atenção de modo especial para aquelas questões capazes de interessar ao jurista moderno, fornecendo-lhe novas 
idéias e material para reflexão. Não nos encega alguma vã pretensão de realizar trabalho novo, nem mesmo mais completo ou original, mas acreditamos que a breve epítome deste tema, que agora passamos a apresentar, contribuirá em alguma medida para aclarar essas questões e tornar possível o traçado de um paralelo entre o matrimônio tal como existia na Roma antiga e aquele nosso contemporâneo.

\section{Il O Conceito Romano de Família}

O matrimônio é, naturalmente, o instituto fundamental do Direito de Família. Tanto em Roma quanto em nossos dias, a noção de família ou união familiar se desenvolve a partir do casamento e da prole que dele se origina. Assim sendo, torna-se impossível discorrer sobre o caráter próprio do vínculo matrimonial sem antes tecer ao menos algumas breves considerações sobre o contexto institucional em que ele se insere, de acordo com o conceito do povo.

Etimologicamente, a palavra familia deriva do vocábulo osco famel, que significa propriamente "escravo" ' Daí resultou a palavra latina famulus, de igual significado, e que persiste no português ("fâmulo"), com o sentido de criado ou serviçal. Um relato dessa etimologia e da evolução semântica sofrida pela palavra chegou a nós pelo De Verborum Significatione de Sexto Pompéio Festo, que nos diz:

\section{Tradução Nossa}

Familia antea in liberis hominibus Anteriormente se dizia familia em se dicebatur, quorum dux et princeps tratando de homens livres, cujo líder e generis vocabatur pater familiae, chefe do grupo era chamado unde familiam nobilium Pompeiorum, paterfamiliae, donde a família dos Valeriorum, Corneliorum. Et nobres Pompeus, Valérios, Cornélios, familiares ex eadem familia. Postea e também os familiares da mesma hoc nomine etiam famuli appelari família. Depois, com esse nome, coeperunt. Famuli origo ab oscis começaram a ser chamados também os dependit, apud quos servos 'famel' famuli (escravos). A origem de nominabantur, unde et familia famulus deriva dos oscos, entre os

1. Cf. Walde, A. Lateinisches etymologisches Wörterbuch, (bearbeitete von J. B. Hoffman), Heidelberg, Carl Winters Universitätsbuchhandlung, 3. Auf., 1938; Emout, A. e Meillet, A Dictionnaire Etymologique de la Lingue Latine, Paris, Klincksieck, $3^{\mathrm{a} e d ., ~ 1951 ; ~ e ~ t a m b e ́ m ~ M a r t i n, ~ F . ~}$ Les Mots Latins, Paris, Hachette, 1976. 
vocata. $^{2}$

quais o escravo era chamado 'famel', donde também foi chamada a família.

O sentido geral, portanto, era de "casa" e o grupo de pessoas que nela viviam e trabalhavam (inclusive os escravos, que para efeitos jurídicos não devem reputar-se pessoas), em oposição ao termo gens, que designava as pessoas descendentes de um mesmo ancestral. Depois, por extensão, passou a significar a própria casa em sentido material; entendida como uma unidade econômica que englobava também os instrumentos de trabalho, os animais domésticos, além dos escravos, as terras cultivadas e tudo o que fosse indispensável à vida da família.

Com base em tais dados observa Sachers $^{3}$ que, no que interessa à linguagem jurídica, o vocábulo "familia" aparece nas fontes com três significados:

a. Em seu sentido original de escravos domésticos, famulagem. Encontramos sinais dessa semântica antiga, e.g., em:

\section{Tradução Nossa}

D. 21, I, 2, Ulp. lib. I ad ed. Familiae Estão contidos no nome de família appelatione omnes qui in servitio sunt todos aqueles que estão sob a continen-tur, etiam liberi homines, qui escravidão, e também os homens livres ei bona fide serviunt, vel alieni: que de boa-fé servem como escravos, accipe eos quoque qui in potestate ou os alheios: considera também eius sunt. aqueles que estão sob sua potestas.

b. Em seguida, passou a conter-se no nome "familia" o abrigo e os bens imóveis associados à atividade econômica familiar, ou seja, casa, curral e horta. Bem mais tarde, quando as terras de cultivo passaram a ser admitidas como propriedade familiar, também elas foram incluídas sob aquela denominação.

2. Citado cf. a edição de De Casatis, C. Charles Casati, Jus Antiquum, Paris, Firmin-Ditot \& Marchal-Billard, s/d, p. 250.

3. Sachers, E. "Paterfamilias", in Realencyclopädie der Classischen Altertumswissenschaft, v. 18, t. 4 , c. 2.123 .

4. Na Antigüiidade, e em sua concepção original, a soberania do Estado e a propriedade das terras eram conceitos estreitamente ligados. Destarte, a terra não pertencia individualmente aos particulares, mas pessoalmente ao monarca ou coletivamente ao conjunto de todos os cidadãos. Foi assim nos primórdios de Roma, onde não se conhecia, a princípio, o domínio privado de terras. Quando muito, era possivel ao particular ser proprietário de sua própria vivenda ou de pequenos lotes utilizados como 
Depois, incluiu-se até mesmo o gado grosso (mulae, equi, asini, cf. Catão, De Agricultura, 138). Dai o novo sentido de "familia" como o conjunto de todo o patrimônio familiar. Com esse sentido patrimonial, a palavra aparece na Lei das XII Tábuas (cf. reconst. Godefroy):

\section{Tradução Nossa}

Lex XII Tab., $V$ - (4) Si intestato moritur, cui suus heres nec sit, adgnatus proximus familiam habeto. (5) Si adgnatus nec escit, gentilis familiam nancitor.
(4) Se morrer sem fazer testamento alguém que não tenha herdeiros, que o agnado tenha a família (i.e., a herança). (5) Se não houver um agnado, um parente (i.e., da mesma gens) receberá a família (i.e., a herança).

Também na jurisprudência clássica ocorre tal emprego, como por exemplo no seguinte fragmento de Ulpiano, que trata da instituição de fideicomisso em testamentos:

\section{Tradução Nossa}

\section{36,1,15 Ulp. lib. IV fideicomiss. - 7. Por conseguinte, se a alguém for}

7. Proinde, qui hereditatem rogatur pedido que restitua a herança, será ele restituere, is demum compellitur compelido a restituí-la exatamente. 8. restituere. 8. Sed et si quis 'bona' Mas também se alguém for solicitado rogatus sit, vel 'familiam' vel a restituir os 'bens', ou a 'familia', ou o 'pecuniam' rogetur vel 'universam rem 'dinheiro' ou 'todo o meu patrimônio'. meam'

No fragmento acima, o jurisconsulto exemplifica as diversas formas pelas quais o testador usava, em sua época, denominar o conjunto de seus bens, e entre elas está o termo "família" Também com esse sentido a palavra aparece em

jardim ou pomar (a tradição, à guisa de explicação para o fato, alude aos bina iugera de terra que Rômulo, o legendário fundador e primeiro rei de Roma, teria deixado em legado para cada um dos cidadãos romanos). O território fora da cidade, destinado à atividade pastoril ou à agricultura extensiva, era considerado ager publicus, insuscetivel de apropriação privada. Somente mais tarde, e sobretudo com o desenvolvimento da agricultura intensiva, começaram a ser distribuídos aos cidadãos lotes de terra, que passavam a reputar-se ager privatus e objeto de propriedade particular (dominium ex iure Quiritium). Ver uma síntese a esse respeito em Arangio-Ruiz, Vincenzo. Istituzioni di Diritto

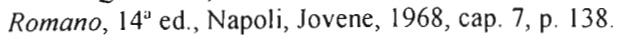


expressões como actio familiae esciscundae, nome da ação que tinha por objeto a partilha dos bens da família. ${ }^{5}$

c. Finalmente, no seu sentido próprio e jurídico (família agnatícia), é um grupo de pessoas sujeitas à potestas de um mesmo paterfamilias (Ulp. D. 50, 16, 195, 2), o que inclui todos os descendentes, a mulher casada cum manu e as esposas dos filhos e netos. Ao lado dessa família proprio iure, mantinha-se, para alguns efeitos jurídicos, a chamada família communi iure, compostas pelos agnados que estariam submetidos a um mesmo paterfamilias caso este estivesse vivo.

No período clássico, a família em sentido estrito é a proprio iure, e o emprego do vocábulo com qualquer dos outros dois significados é mero resquício de usos antigos. ${ }^{6}$ É sobre esse conceito de família que doravante passaremos a discorrer. Note-se desde já que uma tal noção destoa inteiramente do que entendemos hoje por família. A dita "família natural" constituída por um casal e seus filhos, é, na verdade, mais uma instituição social do que jurídica, regida não-só pelo direito, mas principalmente pela moral, pelos costumes e pela religião. Em Roma, as normas jurídicas sobre a família natural praticamente não existiam, absorvida que esta estava pela família proprio iure. ${ }^{7}$ Entre nós, ao contrário, o sentido técnico usual de família na linguagem jurídica é o de família natural. ${ }^{8}$

Quanto à natureza e origem da família romana, muito se discutiu. Para Fustel de Coulanges, ${ }^{9}$ a religião foi a norma constitutiva da família antiga. Fazer parte da família significava participar do culto doméstico, invocar o fogo sagrado, oferecer sacrifícios aos mesmos manes. O princípio do parentesco não era o fato material do nascimento, nem tampouco o afeto natural, mas o culto religioso. E não se tratava da religião de Júpiter e dos outros deuses do Olimpo, que se celebrava nos templos públicos, mas sim a religião doméstica, dos lares e penates de cada família.

Isso explicaria, por exemplo, o instituto da adoção: não importava quem fossem os pais naturais do indivíduo, sua família seria aquela em cujos cultos 195,1 .

5. Sobre os dois primeiros sentidos da palavra familia mencionados acima, ver Ulp. D. 50, 16,

6. Cf. De Martino, Francesco. "Famiglia (Diritto Romano)". in Novissimo Digesto Italiano.

7. Cf. Bonfante, Pietro. Corso di Diritto Romano, v. 1, Sampaolesi, Roma, 1925, pp. 184 e ss.

8. Veja-se, como exemplo, a Constituição Federal, art. $226, \S \S 3^{\circ} \mathrm{e} 4^{\circ}$.

9. Fustel de Coulanges, A Cidade Antiga, (trad. Fernando de Aguiar), Lisboa, Livraria Clássica Editora, $8^{\text {in }}$ ed., s/d. Ver livro II, caps. 1 a 5. 
sagrados ele fosse introduzido, com exclusão de todas as outras. O adotado passava a cultuar os manes da família adotiva, renunciando à sua própria. A partir daí, rompiam-se todos os seus vínculos de parentesco anteriores, e seus parentes naturais passariam a ser para ela estranhos, pois já não participavam dos mesmos cultos. Idêntica explicação poderia ser dada ao casamento cum manu. O inverso, por sua vez, acontecia com a emancipação: o emancipado era excluído da família e, em princípio, também do culto doméstico.

O paterfamilias, como senhor e mestre vitalício do lar e chefe da religião doméstica, era quem procedia à admissão de novos membros, quer pela adoção, quer pela aceitação dos recém-nascidos por meio de ato religioso solene o que explicaria o ius exponendi que the assistia. Diante disso, não surpreende a afirmação de Gaio:

\section{Tradução Nossa}

D. 50, 16, 196, 1 Gai lib. XVI ad ed. É evidente que os filhos das mulheres prov. Feminarum liberos in familia não pertencem à família delas, porque earum non esse palam est, quia qui os que nascem seguem a família do nascuntur patris familiam sequuntur. pai.

Ao lado dessa tese que explica a família romana com base na religião, surgiu a famosa teoria de Bonfante. Para ele, ${ }^{10}$ na sua função própria, a família era primordialmente um organismo político, surgida com escopo de defesa. Seria, de certa forma, um proto-Estado em miniatura, do qual o paterfamilias era chefe supremo. A patria potestas corresponderia, então, e perfeitamente, à soberania dos corpos políticos, exercida na mesma extensão e nos mesmos motivos de ordem de uma sociedade política; por isso, era por vezes chamada, em analogia com termos de Direito Público, de imperium domesticum."

O paralelismo com o Estado é total para Bonfante: a família tem auspicia e sacra privata, em oposição aos publica; ela é, como o Estado, exclusiva: não se podia pertencer a duas famílias, como não se podia ter mais de uma cidadania; e a família se apresentava ao exterior como uma unidade compacta:

10. Corso / (cit. nota 7 supra), cap. 1, pp. 5 e ss.

11. Id. ibid., p. 69. 
somente o paterfamilias, como seu representante político (como um chefe de Estado) podia estabelecer relações com o exterior.

Em consonância com uma tal concepção, a origem da família romana se explicaria pelo fato de que, nas sociedades primitivas, antes da formação do Estado, não havia um organismo único de poder supremo para manter a ordem, mas uma pluralidade de organismos políticos (que na primitiva sociedade romana eram, em grau crescente de abrangência, a família, a gens e a tribo). Cabiam à família, como organismo político, tarefas de organização interna e medidas de defesa externa.

Quando surge uma autoridade estatal, esta não se exerce sobre os indivíduos, mas sobre os grupos e seus chefes, sendo a família o único organismo independente e compacto perante o Estado. No que tange às relações políticas (voto, exercício das magistraturas, etc.), a civitas não se detinha diante da família, e tanto o paterfamilias quanto seus filhos eram cidadãos em pé de igualdade. Mas, na esfera privada, o Estado não intervinha no interior da família, e em época clássica todo o direito privado era verdadeiramente o direito dos paterfamilias.

Não se pode negar que existem dados concretos que, em parte, corroboram a teoria de Bonfante. É sabido que em Roma, ao contrário da Grécia, a relação patriarcal, própria das grandes comunidades gentílicas, perdurou mesmo quando os pequenos grupos familiares tomaram o seu lugar. Po̊r isso Gaio afirmava que a patria potestas era instituto romano desconhecido dos outros povos (G. 1, 55), o que não é rigorosamente verdadeiro.

O paterfamilias não era só o guardião dos usos e costumes dentro do círculo familiar, mas também the cabiam, por - digamos assim — delegação estatal, poderes "legislativos" para a criação de normas que regessem as relações internas da família, e judiciais para julgar e punir os seus membros que as violassem. No interior da família o Estado basicamente nunca interferiu, a não ser em tardio período pósclássico; e o paterfamilias foi sempre reconhecido como verdadeiro senhor das pessoas a ele submetidas, até a época justinianéia. ${ }^{12}$

A teoria de Bonfante foi recebida com entusiasmo e encontrou muitos seguidores, principalmente na Itália. Tem sido, no entanto, combatida, sobretudo 
pela doutrina alemã. Max Kaser ${ }^{13}$ sumariza as críticas a Bonfante em dois tópicos principais: a. tal teoria explica a relativa independência da família com relação ao exterior, mas não o poder absoluto do paterfamilias no seu interior; e b. ela não explica por que esse poder não deixou de existir quando, com o surgimento do Estado, a função política da família perdeu a razão de ser.

Embora se reconheça a importância e o poder sugestivo dessa teoria, ela tem perdido o seu prestígio mesmo na Itália, ${ }^{14}$ e hoje é acatada cum grano salis. O que parece certo, porém, é que a família romana provém da desagregação das comunidades gentílicas, decorrentes, entre outros fatores, da mudança do regime econômico primitivo. ${ }^{15}$

\section{III - O Casamento Romano}

Esperamos ter assinalado, nesta breve exposição, o caráter especial da família romana, que pela sua própria origem histórica apresenta feições bem distintas das da família de nosso tempo. Também o seu papel político no contexto social da época era bem mais significativo.

Da mesma forma, o conceito romano de casamento difere radicalmente do conceito moderno. Bonfante o entende como a mera "convivência do homem com a mulker, sob a autoridade do marido, com intenção efetiva $e$ contínua de ser marido e mulher" 16 Os únicos requisitos eram a convivência (considerada não em sentido material, mas ético e social, com efetiva subsistência de relações morais e afetivas: é o honor matrimonii) e a intenção de serem cônjuges (affectio maritalis). ${ }^{17}$ A simples existência desses requisitos gerava o casamento, independentemente da conventio in manum, que era o ato solene pelo qual a mulher saía da família paterna e entrava na do marido, submetendo-se ao poder do seu paterfamilias, que nesse caso recebia o nome de manus.

13. Kaser, Max. "Der Inhalt der patria potestas", in Zeitschrift der Savigny-Stiftung, 58 (1938), pp. $62-87$. p. 935

14. V., e. g., Pugliese, Giovanni. Istituzioni di Diritto Romano, Torino, Giapichelli. $2^{\star}$ ed., 1990,

15. Cf. De Martino, "Famiglia", (cit. nota 6 supra).

16. Corso I (cit. nota 7 supra), p. 187.

17. Ver porém uma análise critica da doutrina tradicional a esse respeito em Moreira Alves, José Carlos. "A Natureza Jurídica do Casamento Romano no Direito Clássico", in Revista da Faculdade de Direito da Universidade de São Paulo, v. 90 (1995), pp. 3-49. 
Nunca será demais repetir e salientar esse fato primordial: casamento e conventio in manum eram duas realidades distintas e na verdade nenhuma relação tinham uma com a outra. A contração de núpcias era vista em sua origem como um mero fato da vida social, e nenhuma forma jurídica ou celebração solene era exigida pelo direito. Seus pressupostos não eram de forma alguma controlados ou verificados pela autoridade estatal. Uma ação judicial para investigar a atual existência ou-não de uma relação conjugal válida entre duas pessoas perfeitamente imaginável no Direito brasileiro - seria algo inusitado para o pensar romano: desde que não houvesse impedimentos legais para o matrimônio, estar casado ou divorciado eram possibilidades a todo momento abertás ao casal, a seu livre arbítrio e talante e independentemente de quaisquer requisitos formais ou burocráticos. Em última análise, para saber se um determinado casal era ou-não legitimamente casado, bastaria averiguar se tinham ou-não intenção de sê-lo. Pela mesma razão, tampouco a figura do casamento putativo, conhecida do Direito moderno, faria algum sentido na concepção romana de matrimônio.

Importa, portanto, entender que as formas da conventio in manum não constituem celebração de matrimônio, o qual, ao contrário era um pressuposto social daquelas. Contrariamente ao que se sói dizer, é falso supor, por exemplo, que o usus fosse uma "forma de casamento" Muito ao contrário, o usus era um modo de aquisição do poder de manus pelo homem que já estivesse casado com uma mulher há um ano, como nos deixa claro Gaio:

\section{Tradução Nossa}

Gai 2, 3 Usu in manu conveniebat Submetia-se à manus por meio do usus quae anno continuo nupta aquela que permanecesse casada por perseverabat. um ano contínuo.

Verifica-se, portanto, que um dos requisitos do usus era precisamente que a mulher já estivesse casada (nupta) com o homem. É certo que a conventio in manum costumeiramente acompanhava o matrimônio, tendo por finalidade prática e fundamento original trazer a esposa para a família agnatícia do marido. Mas de um ponto de vista estritamente jurídico, a abstração da conventio in manum do fato social do conjúgio era tão grande, que a levou em casos especiais a ser usada até para finalidades completamente estranhas a ele (coemptio fiduciaria, cf. Gai. 1, 114). 
Mesmo a deductio in domum, embora tradicional e importante do ponto de vista social e religioso, não era essencial para a realização do casamento, salvante a hipótese do casamento inter absentes ${ }^{18}$ (Pomp. D. 23, 2, 5). Mesmo nesse caso, não nos parece haver propriamente exigência formal de uma cerimônia, mas a simples necessidade de patentear o fato social das núpcias. Uma vez que o noivo não está presente, há mister de se ter presente algum indício que demonstre a existência do honor matrimonii. A condução da noiva à casa do marido (quasi in domicilium matrimonii, bem explica Pompônio) torna evidente aos olhos de todos que os noivos se reputam casados, e que a mulher está entrando na casa do homem na condição de esposa. Em coerência com essas idéias, não se admitia, em contrapartida, que a noiva se casasse per nuntium ou per litteras, sendo reservada essa forma apenas para o homem: somente a introdução da noiva no lar conjugal evidenciava a condição de casados - que ainda assim continua sendo um mero fato social.

Verifica-se então que o casamento dito sine manu na verdade carece inteiramente de substrato juridico, como bem observa Kunkel, ${ }^{19}$ ensejando unicamente o surgimento de uma vida em comum, sem o caráter de uma relação jurídica - embora traga, inegavelmente, consequiências momentosas para a esfera jurídica. Apenas nesse sentido, a condição de casado (no Direito Romano) assemelha-se muito à posse, o que não é novidade para a ciência romanística, tendo já sido observado muitas vezes o paralelismo entre os institutos. A comparação com a posse parece-nos muito significativa por assinalar o caráter de mero estado de fato do matrimônio romano. Tal como a posse, o estado de casado não se recuperava automaticamente e ex vi legis em razão do ius postliminii:

\section{Tradução Nossa}
D. 49. 15. 14. I Pomp. 3 ad sab. Non
O marido não recupera a esposa pelo
ut pater filium, ita uxorem maritus direito do postliminium, assim como iure postliminii recipit: sed consensu redintegratur matrimonium. ${ }^{20}$ recupera o filho: mas pelo consenso é reintegrado o matrimônio.

18. Cf. e. g. Ehrhardt, Arnold. "Nuptiae" in Realencyclopädie der Classischen Altertumswissenschaft, v. 17, t.2, c. 1.478-1.489.

19. Kunkel, Wolfgang. "Matrimonium". in Realencyclopädie der Classischen Altertumswissenschaft, v. 14, t. 2, c. 2.238 .

20. Cf. também Paul. D. 49, 15,8, que reproduz o conteúdo deste fragmento quase na mesma literalidade. Acerca da posse, confrontar com Pap. D. 4, 6, 19. 
As razões disso são evidentes: pelo postliminium o cidadão romano libertado do cativeiro no estrangeiro recuperava todos os seus direitos, que na verdade continuavam retidos, em suspenso (omnia iura civitatis in personam eius in suspenso retinentur, Gai. D. 28, 5, 32, 1). O casamento (sine manu, bem-entendido), não sendo um direito, mas um estado de fato (tal como a posse), precisava ser recuperado mediante a renovação daquela que era a sua única causa constitutiva: o livre consenso entre os cônjuges.

É, portanto, equivocada a tradicional afirmação de que haveria "duas espécies" de casamento no Direito Romano, quais sejam cum manu e sine manu. Essa dicotomia é inteiramente alheia às fontes romanas, e vem sendo criticada pela melhor doutrina romanística. ${ }^{21}$ Em verdade só havia uma maneira de contrair núpcias em Roma: pela mútua concordância na affectio maritalis. A aquisição ou-não do poder da manus pelo marido era uma questão que em nada afetava a existência do matrimônio, implicando apenas a entrada ou-não da mulher na família proprio iure do marido. Não pode restar dúvidas de que era assim que o instituto era compreendido pelos romanos, como nos revela a seguinte passagem de Aulo Gélio (Noctes Atticae, 18, 6, 9):

\section{Tradução Nossa}

Matrem autem familias appelatam Chamou-se de mater familias somente esse eam solam, quae in mariti manus mancipioque aut in eius, in cuius maritus, manu mancipioque esset, quoniam non in matrimonium tantum, sed in familiam quoque mariti et in sui heredis locum venisset. aquela que está submetida à manus e ao poder do marido, ou daquele a cujo poder o marido estivesse submetido, porque veio não-somente ao matrimônio, mas também à família e à situação de herdeira.

Esse autor - que não era jurista, mas literato - assinala com clareza que na consciência social da época a mulher casada sine manu não deixava de ser

21. Cf. Volterra, Edoardo. "Matrimonium". in Enciclopedia del Diritto, v. 25, p. 755, n. 7. Mas é muito pertinente a crítica de Kaser, o qual, admitindo embora que uma tal dualidade seja estranha à verdade revelada pelas fontes, ressalta que o fato social de que o casamento fosse celebrado ora acompanhado da conventio in mamu, ora sem ela, é uma realidade histórica e justifica o uso, por simplicidade, das expressões "casamento cum manu" e "casamento sine manu" (Kaser, Max. Römisches Privatrecht, v. 1, München, Beck, 1955, p. 64, nota 6). Parece-nos, de fato, que é o caso de condenar-se a falsa noção conceitual, e não o simples emprego de tais expressões. 
considerada esposa (in matrimonium venit); a única diferença é que a esposa cum manu, além de estar casada, também entrava para a família do marido (in familiam quoque venit).

Partamos então para uma breve consideração do conceito romano de matrimônio. Modestino:

Nas fontes, a definição mais conhecida de matrimônio é a de

Tradução Nossa
D. 23, 2, I Modest lib. I reg. Nuptiae
As núpcias são a união do homem e da sunt coniunctio maris et feminae et mulher e o consórcio de toda a vida, consortium omnis vitae, divini et humani iuris communicatio. participação do direito divino e humano.

Esse fragmento tem sido increpado por vários autores, inclusive Bonfante, $^{22}$ de interpolação justinianéia com influência cristã. No entanto Albertario $^{23}$ defende a sua autenticidade, observando que bem se aplica ao casamento cum manu. Também Kunkel ${ }^{24}$ admite que a definição geral de Modestino provavelmente tinha em vista originalmente a confarreatio. A communicatio iuris divini seria, para Modestino, uma conseqüência desse casamento, dado que a mulher seria então admitida nos sacra do culto doméstico do marido; à época de Justiniano essa mesma expressão era interpretada como requisito para o casamento religioso cristão, já que era exigida a não-existência de disparitas cultus. É uma mera alteração do sentido das palavras de Modestino para Justiniano, uma duplex interpretatio, e não uma interpolação.

Tampouco a coniunctio maris et feminae é indício de influência cristã, nem deve ser entendida como exigência de conjunção carnal para que se efetivasse o casamento (como era exigido no Direito Canônico); tanto que era possível o casamento com o homem ausente, desde que a deductio uxoris in domum fosse feita no seu domicílio (Pomp. D. 23, 2, 5, pr.). A coniunctio, para Albertario, indicava

22. Corso I (cit. nota 7 supra), p. 193

23. Albertario, Emilio. "La Definizione del Matrimonio Secondo Modestino", in Studi in Memoria di Aldo Alberioni, Padova, Cedam, 1935, pp. 243-256

24. "Matrimonium" (cit. nota 19 supra), c. 2.281 ss 
não um ato físico, mas um elemento socialmente relevante para a finalidade éticosocial do matrimônio. Ademais, em Inst. I, 9, 1 aparece a expressão viri et mulieris coniunctio (mais delicada do que maris et feminae), que os compiladores justinianeus certamente teriam preferido se pretendessem fazer uma interpolação.

O que mais incomoda aos críticos é o consortium omnis vitae, que se aplica bem ao casamento cristão, mas não ao romano, nem mesmo ao cum manu, que também podia desfazer-se a qualquer momento. Solazzi ${ }^{25}$ observa que o vocábulo consortium é raríssimo na jurisprudência clássica, e não aparece antes do séc. IV aplicado ao matrimônio. Isso é bem verdade, pois Ehrhardt, ${ }^{26}$ consultando o V.I.R., constatou que a palavra só aparece duas outras vezes no Digesto (D. 14, 2, 5 pr. e D. $17,2,52,8$ ), sempre usada para designar pessoas de uma mesma família, e não cônjuges. E em D. 27,1,31,4 fala-se de fratres consortes.

Mas Albertario $^{27}$ explica que, sendo o matrimônio instituto social antes que jurídico, o jurista não podia simplesmente ignorar o modo como a sociedade o via. E isso nos mostra, e.g., Quintiliano (Declam. 247): "uxor est quae femina viro nuptiis collocata in societatem vitae venit" (a esposa é aquela mulher que é unida ao marido pelas núpcias em sociedade na vida). Além disso, saliente-se que omnis vitae não deve ser entendido como "para toda a vida" e sim "em todas as coisas da vida".

E Ehrhardt considera o uso da palavra consortium, ao contrário, como prova de autenticidade do fragmento, dado que a mulher no casamento cum manu entra para a família do marido como consors dele e dos filhos. Esse o verdadeiro sentido da expressão in loco filiae, que define a situação da mulher na família. Longe de significar uma posição subalterna ao marido, significa ao contrário que ela tinha os mesmos direitos dos demais alieni iuris, cf. G. I, 115b: "placuit eam filiae iura nancisci" (pareceu certo que ela adquirisse os direitos de filha). Lembremos que a mulher se submetia ao paterfamilias como chefe do grupo familiar, e não ao marido como cônjuge.

É com base nesses argumentos que Ehrahrdt propugna que a mulher romana não se situava verdadeiramente em uma condição inferior ao marido 27 e ss.

25. Solazzi, Siro. "Consortium Omnis Vitae", in Annali dell 'Universitá Macerata, v. 5, 1929, pp.

26. Ehrhardt, Arnold. "Consortium Omnis Vitae": in Zeitschrift der Savigny Stiftung, 57 (1937), pp. 357-366.

27. Cit. nota 23 supra. 
mesmo no casamento cum manu sendo antes considerada socia e parceira dele na vida (cf. C. 9, 32, 4, pr. Imp. Gordianus A. Basso - Adversus uxorem, quae socia rei humanae atque divinae domum suscipitur...). Em sentido pessoal e moral, de uma união de almas, essa idéia já se encontra nos filósofos gregos e pode ter influenciado os jurisconsultos romanos. Ademais, socialmente a mulher romana era altamente considerada e não-raro participava da vida política (ao contrário da mulher grega), sendo vista como uma figura nobre, imponente e severa.

O nome matrona era reverenciado como um título honroso, e a esposa compartilhava também todos os títulos nobiliárquicos do marido (cf. Ulp. D. 1, 9, 1, 1 e D. $1,9,1,8$ ), sendo inconcebível em Roma o chamado casamento morganático. ${ }^{28}$ Analogamente ao hábito vigente em nossos dias, a mulher casada cum manu incorporava, inclusive, o nome gentílico do marido, o que se relaciona com a antiga fórmula recitada pela noiva na cerimônia da coemptio, e mencionada por Cícero no Pro Murena, 27: "tu Gaius, ego Gaia" (também atestado por diversas inscrições antigas, cf. o já citado Kunkel). ${ }^{29}$ Principalmente no período pós-clássico intensificou-se a noção de que existia para os cônjuges o dever de honrar-se reciprocamente, sendo proibidas as ações infamantes entre eles (Gai. D. 25, 2, 2). Foi em razão deste último preceito, por sinal, que se desenvolveu a actio rerum amotarum, em substituição à actio furti (que era infamante), para que o cônjuge pudesse reaver bens subtraídos de seu patrimônio pelo outro cônjuge. ${ }^{30}$

Em todos os sentidos, a manus deve ser entendida como um poder protetor, e não opressor da mulher, ao contrário do que a mentalidade moderna tende a supor. Entrando para a família in loco filiae, passava a mulher a gozar da mesma proteção devida aos filii familias, o que incluía até mesmo o direito a alimentos, ${ }^{31}$

28. Bonfante, Corso I (cit. nota 7 supra), 188

29. "Matrimonium", (cit. nota 19 supra), c. 2.281, letra "a"

30. Sobre este assunto o melhor estudo já realizado é o de Wacke, Andreas. Actio Rerum Amotarum, - Forschung zum römischen Recht, Böhlau, Köln, 17. Abhandlung, 1963.

31. Ao que parece esse dever do paterfamilias começou com Antonino Pio e foi ampliado mais tarde. A idéia de um tal dever imposto ao pai é uma exceção à estrutura própria da familia romana. Segundo E. Sachers ("Paterfamilias", in Realencyclopädie der Classischen Altertumswissenschaft, v. 1 8, t. 4 , c. 2.123 ss.), essa norma é compatível com a idéia de um poder paterno se entendida em dois sentidos: a. vendo o imperador na negação dos alimentos um abuso desse poder; b. sendo dado ao fillho um amparo estatal, ao lado da proteção da pátria potestas, com base no qual fossem exigidos os alimentos. Mas a decadência desse poder é patenteada pelo forma com que se trata no Digesto do direito de alimentos do filho com relação ao pai e do pai com relação aos filhos em uma só regra, como se estivessem em igualdade de situação (Ulp. D. 23, 3, 5). 
que não assistia à mulher casada sine manu. ${ }^{32} \mathrm{O}$ homem tinha, ainda, o direito e o dever de perseguir judicialmente injúrias praticadas contra a sua mulher (Ulp. D. 47, $10,1,3)$ o que, porém, também valia para o casamento sine manu.

Em último lugar, poder-se-ia indagar como se diferenciava o casamento do concubinato, uma vez que o primeiro não dependia de formalidade alguma, caracterizado apenas pela união estável do homem com a mulher. $\mathrm{O}$ concubinato era igualmente uma união estável, mas sem a affectio maritalis e sem o honor matrimonii. Era muito freqüente sobretudo entre as pessoas que se não podiam casar em razão de algum impedimento legal que existisse para o seu matrimônio. Era, por exemplo, o caso das leis matrimoniais de Augusto, que introduziram diversas proibições de casamento em razão de diferença de classes sociais (e. g. entre ingênuos e libertos; ou entre patrícios e plebeus, o que era proibido até a promulgação da Lex Cannuleia em 455 a.C.). Não era considerado indecoroso, e até pessoas de alta estirpe tinham concubinas. Um homem podia ter várias concubinas, e até mesmo uma mulher podia ser concubina de vários homens. O concubinato podia se converter em casamento, bastando que se alterasse a vontade das partes, surgindo a affectio maritalis. ${ }^{33}$ Vê-se que em muito se afasta da

Os textos das fontes a esse respeito são pouco claros, mas Emilio Albertario ("Sul diritto agli Alimenti", in Studi di Diritto Romano, v. 1, Milano, Giuffrè, 1933, pp. 249-280) chegou à conclusão de que, na idade imperial clássica:

a. na familia legítima, o direito a alimentos surge relacionado com o elemento potestativo, reciprocamente entre o paterfamilias e as pessoas a ele submetidas;

b. em um momento posterior, prevalecendo o vinculo cognatício, há também obrigação alimentar entre o pai e os fillhos emancipados.

c. a mãe não se inclui nesse direito, salvo a casada cum mamu, como qualquer outro alieni iuris

d. na familia ilegitima, a obrigação existe só entre a mãe e o filho natural (vulgo quaesitus), mas o pai natural está isento.

e. não há qualquer indício dessa obrigação entre colaterais ou afins.

Houve profundas alterações em época justinianéia, não havendo mais diferença entre a familia legitima e a ilegítima: na legitima passa a existir obrigação entre mãe e fïlho, e, na ilegitima, entre pai natural e fillho, e até entre colaterais

32. O único fragmento em que se delineia o dever de alimentos entre cônjuges (Ulp. D. 24, 3, 22, 8) é apontado por Albertario (cit. nota 31) como interpolado. De todo modo, mesmo no periodo justinianeu um tal dever só aparece excepcionalmente (cf. Kaser, Max. Römisches Privatrecht II, München, Beck, 2. Aufl., 1975, §218, p. 174 e nota 34; Kaser também está de acordo em que D. 24, $3,22,8$ seja itp.).

33. Perozzi, Silvio. Istituzioni di Diritto Romano, Athaeneum, Roma, $2^{\mathrm{a}}$ ed., v. 1, 1928, pp. 371 e ss. Inversamente, poderia, em princípio, ocorrer o inverso - isto é, pela cessação da affectio maritalis já que no casamento esta deveria estar sempre presente, não bastando que existisse apenas no início da relação marital (cf. e. g. Mayer-Maly, Theo. Römisches Privatrecht, Wien, Springer Verlag, 1991, p. 25 , expressando a communis opinio. Mas veja-se uma vigorosa confutação da tradicional doutrina dominante em Moreira Alves, cit. nota 17 supra). 
concepção atual de concubinato. Muitas ligações que hoje se reputam concubinato são verdadeiros casamentos de facto, e no Direito Romano seriam considerados matrimônios legítimos.

Diante disso tudo, Bonfante ${ }^{34}$ estabelece com muita propriedade a seguinte comparação entre o casamento romano e o casamento moderno:

a. o casamento romano era uma relação social, e o direito nada mais fazia do que reconhecer sua existência; o casamento moderno é uma relação artificial criada pelo dịreito, e independente da relação factual existente entre o homem e a mulher;

b. em Roma, o vínculo era estabelecido informalmente pela vontade constante e permanente das partes, dissolvendo-se quando desaparecesse a consistência e a continuidade da vida comum; no casamento moderno, o vínculo se estabelece por consenso solene, e uma vez estabelecido perdura indefinidamente, e independentemente daquilo que na vida social é o conteúdo e a base do matrimônio.

IV - Algumas Considerações sobre o Direito à Coabitação

No matrimônio do Direito Civil moderno entende-se que, embora por um lado a coabitação dos cônjuges não seja fundamento nem pressuposto de um casamento válido, por outro lado é a sua conseqüência natural e esperada, haja vista que uma das finalidades da união conjugal é o compartilhamento da vida afetiva e a satisfação da libido do homem e da mulher. Desse modo, conquanto a persistência do convívio do casal não seja, por si, indispensável para a preservação do vínculo matrimonial, é ela considerada um direito e também um dever dos cônjuges. $\mathrm{O}$ abandono do lar conjugal é uma séria infração dos deveres do matrimônio.

De certa forma vinculada à idéia de coabitação está também a de manutenção das relações sexuais entre marido e mulher. Não sendo, tampouco, requisito para que o casamento seja válido, elas são contudo vistas como um direito essencial de ambos os cônjuges - fala-se na doutrina em um ius in corpus, um direito ao corpo do outro cônjuge, ou à fruição do mesmo para fins de remédio à concupiscência. Em contrapartida a esse direito, entende-se que há o dever de cada cônjuge de prestar essa satisfação sensual ao outro — e se fala então em um debitum coniugale. A recusa infundada de cumprir tal débito conjugal é tido como grave ofensa ao outro cônjuge, e até mesmo justa causa para divórcio. 
Qualquer tentativa de traçar paralelos, nesse tocante, com o Direito Romano, parece fadada ao insucesso, em vista das conclusões a que chegamos no item anterior deste nosso estudo. De fato, não há falar em dever de coabitação em Roma, uma vez que a coabitação só poderia perdurar enquanto existisse a affectio maritalis. Cessada esta última, o próprio casamento se desfaria, por desaparecer a condição fundamental que the dá substrato. A idéia de um debitum coniugale é avessa à noção romana de matrimônio. A sua importância moderna como justa causa para divórcio era inexistente em Roma, pois o divórcio prescindia de qualquer "justa causa" não tendo os cônjuges que permanecer casados se qualquer um dos dois não mais o desejasse. Muito ao inverso, imperava entre os antigos quirites a convicção de que as núpcias só se podiam manter pela livre vontade de ambas as partes, não se admitindo que alguém pudesse ser obrigado a permanecer casado à sua revelia, como se depreende da seguinte constituição imperial:

\section{Tradução Nossa}

C. 8, 38, 2 Imp. Alexander A. Do imperador Alexandre Augusto a Menophilo. Libera matrimonia esse Menófilo. Desde há muito tempo antiquitus placuit. Ideoque pacta, ne decidiu-se que os matrimônios devem liceret divertere, non valere et ser livres. E por isso é certo que os stipulationes, quibus poenae pactos para que não seja lícito divorciarinrogarentur ei qui divortium se não são válidos, bem como não se fecisset, ratas non haberi constat. reputam válidas as estipulações pelas PP III non. Febr. Maximo II et quais sejam impostas penalidades ao Aeliano conss. que se tenha divorciado. Publicado no $3^{\circ}$ dia antes das nonas februárias (dia 3 de fevereiro), sendo cônsules Máximo II e Eliano.

Se, portanto, a ausência de um dos cônjuges da habitação comum do casal ou mesmo a recusa em prestar-lhe a satisfação da libido caracterizasse a cessação da affectio maritalis, nada poderia ser feito para impedi-lo, e o matrimônio simplesmente chegaria ao fim. ${ }^{35}$

35. Seguimos a doutrina dominante, segundo a qual a cessação da affectio maritalis era a causa da extinção do vinculo conjugal. A opinião dissonante de Moreira Alves (cit. nota 17 supra) não contraria, no entanto, a essência do que vimos sustentando: seja pelo simples fím da affectio maritalis, 
Não podendo haver coabitação nem casamento sem a affectio maritalis, de outra parte é bem claro que estes dois últimos podiam perfeitamente prescindir do primeiro. Desde que o casal manifestasse o desejo de permanecer casado e devotasse reciprocamente o respeito e a afeição devidos entre marido e mulher, seriam reputados casados, ainda que não coabitassem. As fontes nô-lo revelam com clareza meridiana:

\section{Tradução Nossa}

D. 24, 1, 32, 13 Ulpianus, lib. XXXIII Se a mulher e o marido de fato ad Sab. Si mulier et maritus diu moraram separados por longo período, seorsum quidem habitaverint, sed mas tinham reciprocamente o honor honorem invicem matrimonii matrimonii (o que sabemos ter habebant (quod scimus interdum et sucedido de vez em quando até entre inter consulares personas as pessoas da classe consular), subsecutum), puto donationes non considero não serem válidas as valere, quasi duraverint nuptiae: non doações, tendo perdurado, por assim enim coitus matrimonium facit, sed dizer, as núpcias: pois não é o coito, consensus. mas o consenso que faz o matrimônio.

No fragmento em tela trata-se de uma doação realizada entre cônjuges - as quais, como se sabe, eram eivadas de nulidade. Desnecessário dizer que se trata de casamento sine manu, já que a sujeição da esposa à manus do marido ou do paterfamilias deste implicaria sua absoluta incapacidade patrimonial, tornando qualquer doação juridicamente impossível. No caso, porém, o casal vivia separado, o que deu azo à questão acerca da permanência ou-não do estado de casados. O jurista romano foi bastante incisivo em declarar inequivocamente que a coabitação não era socialmente vista como pressıposto do matrimônio - e lembremos que o casamento era apenas um fato social — noção que era posta em prática até pelas classes elevadas. Por conseqüência, não era válida a doação. Depreende-se disso que o hábito hoje praticado por alguns casais, sobretudo nos Estados Unidos, de residir em casas separadas, já era coisa usual na Roma antiga.

Dessa decisão de Ulpiano de sólito citam-se apenas as últimas palavras, fora do contexto, e alçadas a brocardo jurídico: "consensus facit nuptias" 
Já Justiniano, no último livro do Digesto, acerca das "diversae regulae iuris antiqui" incluiu a máxima:

\section{Tradução Nossa}

D. 50, 17, 30 Ulpianus, lib. XXXVI ad Não é o concúbito, mas o consenso Sab. Nuptias non concubitus, sed que faz as núpcias. consensus facit.

Não é, portanto, novidade alguma repetir que a coabitação e a partilha do mesmo leito não consistiam, no Direito Romano, elemento essencial do matrimônio, nem tampouco um direito dos cônjuges com relação um ao outro.

Parece-nos, no entanto, que há um outro aspecto a ser considerado nessa questão. E realmente, julgamos poder afirmar que, apesar das aparentes evidências em contrário, os romanos na verdade admitiam a existência de um direito à coabitação, de um ius in corpus de um cônjuge sobre o outro. A particularidade do sistema romano é apenas que esse direito não podia ser invocado contra o próprio cônjuge (a quem assisitia o direito de afastar-se do leito e do lar quando bem the aprouvesse, mesmo fazendo cessar a união conjugal, se preferisse), podendo no entanto ser invocado contra terceiros que impusessem óbices à coabitação do casal.

A manifestação mais evidente desse direito está no conhecido interdictum de uxore exhibenda ac ducenda, que competia ao marido para exigir a apresentação e condução da esposa à sua presença, caso a mesma estivesse ilegalmente afastada do lar conjugal por um terceiro.

$\mathrm{Na}$ verdade, o referido interdito pertence a uma "família" de interditos de exhibendo ac ducendo, contidos em D. 43, 24 e D. 43, 25, e que inclui também os interditos de exhibendo ac ducendo homine libero e o de exhibendis ac ducendis liberis. O primeiro era o mais amplo de todos: aplicava-se a qualquer situação em que um homem livre estivesse retido injustamente por alguém. Pouco importava que a pessoa em questão fosse homem ou mulher, sui ou alieni iuris, púbere ou impúbere, desde que se tratasse de pessoa livre (Ulp. D. 43, 29, 3, 1: "hoc enim tantum spectamus, an liber sit ${ }^{\prime \prime}$ ). Era pressuposto que a pessoa estivesse sendo detida dolo malo, isto é, por quem não tivesse o direito de tê-la em seu poder; assim, não se podia usar o interdito, por exemplo, contra o paterfamilias (Ulp. D. h.t. 3.2) ou contra quem, tendo pago o resgate, detivesse um redemptus ab hoste (eod. $\S 3^{\mathrm{o}}$ ). Por outro lado, o interdito tinha o caráter como que de uma ação popular, pois a 
legitimação ativa tocava a toda e qualquer pessoa (eod. $\S$ 9: "Hoc interdictum omnibus competit: nemo enim prohibendus est libertati favere"). Já o interdito de liberis exhibendis só competia a quem tivesse o poder familiar sobre a pessoa detida por terceiro (Ulp. D. $43,30,1$ ): tais por exemplo o paterfamilias ou o marido casado cum manu.

Para o interdito de uxore exhibenda ac ducenda, ${ }^{36}$ que presentemente nos interessa, estava legitimado exclusivamente o marido, e somente em benefício da própria esposa, retida fora do lar por terceiro. Lenel ${ }^{37}$ observa que o interdito de liberis exhibendis sem dúvida se aplicava não-somente à patriapotestas, mas também a todas as relações de poder, aí incluída a manus do marido, como já dissemos; decorre então que com relação ao de uxore exhibenda não se deve pensar na uxor in manu - o que seria uma desnecessária superfetação, um bis in idem mas sim no casamento puro e simples, sine manu.

É um fato espantoso, pois o marido que não detivesse a manus não gozaria de poder algum sobre a esposa, e na verdade não seria nem sequer parente agnatício dela. No entanto, era-lhe reconhecido o direito de exigir a sua volta ao lar de qualquer um que a impedisse. Não há como entender a legitimação ativa a esse interdito, a não ser admitindo que o pretor reconhecia a existência de um direito autônomo à convivência doméstica entre os cônjuges, originado apenas da relação social de matrimônio.

36. Estamos, por simplicidade, falando em um interdito de exhibendo ac ducendo, já que os detalhes do processo romano não nos interessam no contexto deste estudo. Na verdade, como explica Adolph Berger ("Interdictum": in Realencyclopädie der Classischen Altertumswissenschaft, v. 9, t. 2, c. $1.642, \mathrm{n} .12, \mathrm{c})$, o que havia eram dois interditos, um de exhibendo e o outro de ducendo, tanto no caso da uxor quanto no dos liberi ou do homo liber de um modo geral. O primeiro interdito (de exhibendo), tinha por finalidade obter a apresentação da pessoa detida pelo réu, a fím de que se verificasse a sua identidade, bem como o fato de ela estar ou-não injustamente (dolo malo) em seu poder. Somente se o resultado apurado nessa primeira fase fosse positivo seria concedido o segundo interdito (de ducendo), a fim de que a pessoa em questão fosse conduzida ao propositor do interdito e entregue à sua guarda por ordem do magistrado. Podemos dizer, portanto (como o próprio Ulpiano o faz em D. 43, 30, 3, 1), que o interdito de exhibendo é preparatório para o de ducendo. Quanto ao sentido exato de exhibere, salienta Sachers ("Exhibere" in Realencyclopädie der Classischen Altertumswissenschaft, Suppl. 10, c. 191-221), que não era necessário que se apresentasse a pessoa em juizo, ao contrário do que se sói afirmar, sendo suficiente que ela fosse deixada acessível ao impetrante, de sorte que este tivesse a oportunidade de "tê-la diante dos olhos" ("in Augenschein zu nehmen"). Nas fontes encontramos diversas definiçðes de exhibere (Paul. D. 4, 7, 8; Paul. D. 10, 4, 2; Ulp. D. 10, 4, 9, 5; Gai. D. 50, 16, 22)

37. Lenel, Otto. Das Edictum Perpetuum, Aalen, Scientia Verlag, $3^{a}$ ed., 1974, p. 488, n. 4. 
Porém o mais notável é que o interdito podia ser impetrado até mesmo contra o paterfamilias da esposa - o qual, portanto, não a retinha dolo malo, mas no legítimo exercício da sua patriapotestas. Examinemos o seguinte fragmento de Hermogeniano:

\section{Tradução Nossa}

D. 43, 30, 2 Hermogenianus lib. VI Pelo contrário, é mais certo que o pai, iuris epitomarum. Immo magis de até mesmo o que tiver a filha sob a sua uxore exhibenda ac ducenda pater, potestas, seja justamente processado etiam qui filiam in potestate habet, a pelo marido para que lhe seja marito recte convenitur. apresentada e conduzida a esposa.

É de cristalina clareza o pensamento de Hermogeniano nesse sentido: estabelecido o conflito de interesses, o direito à coabitação por parte do marido prevalece até mesmo sobre o poder do paterfamilias. E não deixa de causar estranheza uma tão-incisiva restrição à patriapotestas, um poder que historicamente representa a base da própria estrutura social - e política - de Roma, e tãocaracterístico de sua organização social que ainda Justiniano afirmava (Inst. 1, 9, 2), seguindo Gaio (Gai. 1, 55), ser exclusividade do povo romano. ${ }^{38}$ Lenel $^{39}$ explica que a concessão desse interdito só apareceu em fase bem tardia da evolução do Direito Romano (ou só com Justiniano, segundo Brini), ${ }^{40}$ o que condiz com o fato de que a patria potestas foi sempre vista como um poder absoluto, e o poder público não impôs limitações explícitas ao seu exercício no âmbito doméstico — onde o pater era soberano - salvante, talvez, no direito pós-clássico bem tardio. ${ }^{4}$

38. Cf. já referimos supra, à p. 9.

39. Id., Ibid. (cit. nota 37 supra). 163.

40. Brini, Giuseppe. Matrimonio e divorzio nel Diritto Romano, Bologna, Zanichelli, 1887, p.

41. Essa questão merece algumas palavras à parte na ordem destas nossas argumentações. A idéia de patria potestas como poder absoluto parece ser confirmada pelas fontes. O ius vitae et necis foi afirmado até a época de Constantino (Cod. Theod. 4, 8,6), e somente Valentinian [ o eliminou completamente (C. $9,15,1$ ). Mesmo a condenação de um paterfamilias ao exílio porque matara um filho que havia fornicado com a madrasta - decretada pelo imperador Adriano - não fora motivada pela execução do fillho em si, mas sim pela forma como fora realizada; de fato, o pai organizou uma caçada na qual o filho era a presa. O texto integral é: D. 48, 9, 5 Marc. lib. XIV inst. "Divus Hadrianus fertur, cum in venatione filium suum quidam necaverat, qui novercam adulterabat, in insulam eum deportasse, quod latronis magis quam patris iure eum interfecit: nam patria potestas in pietate debet, 
Em consonância com o texto de Hermogeniano está também o de Ulpiano:

non atrocitate consistere." (Tradução Nossa: Conta-se que o divino Adriano, como um certo homem tivesse matado numa caçada um filho seu que cometia adultério com a madrasta, o deportou para uma ilha, porque o matou mais como um ladrão do que como direito de um pai: pois o pátrio poder deve consistir na piedade, não na atrocidade). Note-se que o direito do pai não é negado: somente se condena a forma cruel como o exerceu. Desse fragmento, a última oração é suspeita de interpolação (cf. Roberti, Melchiorre. "Patria Potestas e Paterna Pietas", in Studi in Memoria di Aldo Albertoni, Padova, Cedam, 1935, pp. 257-270). De fato, durante o período clássico, não se encontram no ius civile limitações ao exercicio da potestas no seio da família. A única exceção conhecida está nas XII Tábuas, no famoso IV, 3: "Si pater filium ter venum duit, filius a patre liber esto." (Se um pai vender o filho três vezes, esteja o filho libertado do pai). Questiona-se se na prática era mesmo irrestrito esse poder. Ihering (Geist des Römischen Rechts, v. 2, t. 1, Leipzig, Breitkopf und Härtel, $3^{\natural}$ ed., 1874, p. 187) acredita que as únicas restrições que havia fossem de caráter moral. Já Max Kaser ("Der Inhalt der patria potestas", in Zeitschrift der Savigny-Stiftung, 58 (1938), pp. 62-87) aponta duas formas de limitação que possivelmente existiriam: os costumes e o direito sacro, os quais formavam, em tempos primitivos, uma unidade indistinta com o direito, mas que dele se separaram aproximadamente no início da República. Apresenta, além disso farta e consistente argumentação contrária aos que pretendem vislumbrar uma tutela jurídica contra abusos da pátrio poder nos relatos de Dionisio de Halicarnasso $(2,15-27)$, que fala de uma pretensa lei de Rômulo que sujeitava à pena de confisco patrimonial aquele que expusesse recém-nascidos, salvo nos casos de nascimentos teratológicos ("monstros"). Também Bonfante (Corso I, p. 77). acha duvidosa a existência de uma sanção civil para esses casos em uma época remota, na qual o direito tinha ainda caráter sacerdotal, e principalmente no campo dos relacionamentos ético-familiares. Outro possivel freio aos abusos seria a atuação dos censores, que por sem-dúvida deveria ocorrer, mas que, ainda na opinião de Max Kaser, dificilmente conseguiria, por si só deter a decadência dos costumes, pois suas armas afora o poder de afastar o transgressor do esnado e da classe eqüestre era apenas a nota censoria, insuficiente como sanção persuasiva. Por essa razão, os imperadores que se empenharam em reavivar os costumes clássicos, como Augusto, não recorreram ao fortalecimento da censura, mas criaram legislação rigorosa a esse respeito. No entender de Bonfante (Corso I cit., nota 7 supra, p. 76) o verdadeiro impedimento aos abusos eram os mores maiorum, os costumes antigos, que não seriam meras regras de moral, como sugeriu lhering, mas normas jurídicas em sentido estrito, derivadas concretamente do uso inveterado e relativas a um organismo político diverso da civitas: constituiriam um direito interno da própria família. Então esses mores maiorum teriam sido os responsáveis pelo estabelecimento da exigência da convocação do chamado consilium domesticum, órgão consultivo que exerceria em conjunto com o paterfamilias as funçð̃es jurisdicionais no lar, sobretudo no tocante ao exercício do ins vitae et necis. A existência dessa exigência, contudo, tem sido contestada pela doutrina recente, que tende a considerá-la mero uso social sem força vinculante (Cf. Guarino, Antonio. Diritto Privato Romano, Napoli, Jovene, $8^{\mathrm{a}}$ ed., 1988, p. 487 e nota ao 47.2, com bibliografia). Apenas tardiamente, no periodo pós-clássico, o Direito assimilou a influência dos costumes e Direito Sacro e impôs verdadeiras limitaçð̃es ao paterfamilias, mormente graças à humanização trazida pelo espírito helenístico, e à influência cristã. No Direito justinianeu, a patria potestas não mais é uma verdadeira jurisdição sobre os próprios filhos, mas um poder limitado de castigá-los na devida forma da domesticae emendationis disciplina. Veja-se e. g. o texto de Ulpiano em D. 48, 8, 2 (que Bonfante considera interpolado): "Inauditum filium pater occidere non potest, sed accusare eum apud praefectum praesidemve provinciae debet." (o pai não pode matar o fillho sem antes ouvi-lo, mas deve acusá-lo perante o praefectus ou o praeses da província). Foi deste modo abolido o ius vitae et necis. $\mathrm{O}$ ius exponendi também foi expressamente vedado (Val. et Grat. C. 8, 51 [52], 2, pr.). 


\section{Tradução Nossa}

D. 43, 30, 1, 4 Ulpianus lib. LXXI ad ed. Si quis filiam suam, quae mihi nupta sit, velit abducere vel exhiberi sibi desideret, an adversus interdictum exceptio danda sit, si forte pater concordans matrimonium, forte et liberis subnixum, velit dissolvere? Et certo iure utimur, ne bene concordantia matrimonia iure patriae potestatis turbentur. Quod tamen sic erit adhibendum, ut patri persuadeatur, ne acerbe patriam potestatem exerceat.
Se alguém quiser levar embora sua filha, que seja casada comigo, ou desejar que lhe seja apresentada em juízo, será que se deve conceder uma exceção processual contra o interdito, caso o pai queira dissolver um matrimônio harmonioso ou respaldado pela existência de filhos? E temos como direito assentado (que sim), para que casamentos harmoniosos não sejam perturbados pelo direito do pátrio poder. Isso também se aplicará, assim, para que se persuada o pai a não-exercer com crueldade o pátrio poder.

Percebe-se aqui o reverso da medalha da situação anterior. Aqui é o pai quem, valendo-se do interdictum de liberis exhibendis, pretende exigir a apresentação de sua filha — casada sine manu com o réu — a fim de obter a separação do casal. Notável a decisão do jurisconsulto: embora não pudesse denegar o interdito - pois o direito do pai era inquestionável - concedeu ao marido a uma exceptio, bloqueando interdito do pai, e baseado no fato de que o matrimônio era bene concordans.

A mais aguçada exegese desse fragmento parece-nos ser a de Glück. ${ }^{42}$ O extraordinário pandectista relaciona o parecer de Ulpiano à constituição de Marco Aurélio mencionada no fragmento do Codex que reproduzimos a seguir:

\section{Tradução Nossa}

C. 5, 17, 5, pr. Diocl./ Maxim. O divino Marco, nosso pai imperador Dissentientis patris, qui initio religiosíssimo, determinou que não consensit matrimonio, cum marito seja considerada válida a vontade

42. Glück, C. F., Ausführliche Erläuterung der Pandekten, v. 26, Erlangen, Palmischen Verlagsbuchhandlung, 1824, §1259b, pp. 256 e ss. 
concordante uxore filia familias ratam non haberi voluntatem divus Marcus pater noster religiosissimus imperator constituit, nisi magna et iusta causa interveniente hoc pater fecerit. * Diocl. Et Maxim. AA. et CC. Scyrioni. * $<$ A 294 d. V k. Sept. Nicomediae CC. Conss. $>$ discordante do pai, que de início consentiu no matrimônio, estando a filha concorde com o marido, a não ser que o pai tenha feito isso por haver intervido uma causa grande e justa.

E de fato bem observou Glück que as palavras velit dissolvere de Ulpiano revelam que, ao se valer do interdito, o pai visava à separação do casal, à dissolução do matrimônio. Portanto, a situação é essencialmente a mesma do caso apreciado por Diocleciano e Maximiano. E a esse respeito já decidiu Marco Aurélio, vedando ao pai essa possibilidade. Vê-se que a antiga condição de total arbítrio do pater sobre o casamento dos filhos há muito se havia alterado. Mas o que causa um pouco de estranheza são as palavras "ut patri persuadeatur, ne acerbe patriam potestatem exerceat" no texto de Ulpiano. Ele fala em persuadir o pai a não ser cruel no exercício de seu direito, e não em privá-lo desse direito. Será que com isso o jurisconsulto quis dizer que, caso o pai perseverasse em sua crueldade e não se deixasse persuadir pelo magistrado, a exceptio seria ineficaz e o interdito concedido? É óbvio que não, pois Ulpiano declara que a intocabilidade do concordans matrimonium era já direito assentado ("certo iure"), e inquestionável. Esse, por sinal, é um princípio já afirmado desde Antonino Pio, como nô-lo demonstra um fragmento das Sentenças de Paulo: PS.5.6.15 "Bene concordans matrimonium separari a patre divus Pius prohibuit" (o divino Pio proibiu que o matrimônio concorde seja separado pelo pai).

O que se verifica, em conclusão, é que, caso o matrimônio seja harmonioso, o pai será eficazmente impedido por uma exceptio do marido, ainda que não se deixe persuadir a desistir de seu intento. Ou antes, seguindo a linha de Glück, podemos dizer que será "persuadido" pela pura e simples aplicação da constituição de Marco Aurélio. Ao que parece, a maneira oblíqua pela qual Ulpiano faz menção a essa diminuição dos efeitos da patria potestas se deve ao respeito de que aquela instituição ainda gozava (cf. nota 41 supra). Talvez pela mesma razão se explique a ênfase dada por Diocleciano e Maximiano ao fato de que o pai "initio consensit": o casamento era válido precisamente porque o pai havia consentido, pois não 
prescindia de sua aprovação (Paul. D. 23, 2, 2). Esse preceito sempre vigorou, e sua menção nos mostra que os imperadores buscavam impor um abrandamento, sem contudo negar-lhe o prestígio. E assim também Ulpiano.

A esse propósito, Hackl ${ }^{43}$ observa que a partir do século II d.C. muitas restrições foram feitas ao uso de tais interditos pelo pater, quando estes contrariassem outros interesses mais merecedores de tutela jurídica. Entre eles o da mãe, a quem se concedia a guarda dos filhos a despeito da patriapotestas do pai, se fosse mais conveniente para o bem-estar da criança (Ulp. D. 43, 30, 1, 3, salientando que isso só era possível "ex iustissima causa") ou quando o pai não fosse pessoa digna ("ob nequitiam patris" Ulp. D. eod. 3.5, insistindo porém em que isso se dava "sine deminutione patriae potestatis").

Observe-se, finalmente, que se esse direito à coabitação podia ser exercido pelo marido até mesmo contra o paterfamilias da mulher, não podia sê-lo contudo ao arrepio da vontade da própria. Ou seja: o pai não podia retê-la contra a vontade do marido, mas este por sua vez não podia forçá-la a voltar se ela não quisesse. Veja-se por exemplo este rescrito de Diocleciano e Maximiano:

\section{Tradução Nossa}

C. 5, 4, 11 Impp. Diocletianus et Se a tua esposa está detida pelos seus Maximianus AA. Alexandro. Si invita pais contra a sua vontade, seja detinetur uxor tua a parentibus suis, chamado o nosso amigo governador da interpellatus rector provinciae amicus província, o qual, sendo a mulher noster exhibita muliere voluntatem apresentada em juízo, e seguindo eius secutus desiderio tuo medebitur. $\quad$ vontade dela, atenderá ao teu desejo.

Vê-se que a esposa do destinatário do rescrito (Alexandre) estava detida contra sua vontade (invita) pelos próprios pais. Os imperadores concedem o interdito ao peticionário, por meio da jurisdição do rector provinciae, mas deixam claro que este só deverá agir "voluntatem eius secutus" Naturalmente, se a mulher não desejasse voltar, não poderia ser compelida a isso, em observância à já-citada regra "libera debent esse matrimonia"

43. Hackl, Karl, "Die Feststellung der Vaterschaft und der väterlichen Gewalt", in Zeitschrift der Savigny-Stiftung (Romanistische Abteilung) 90 (1973), p. 143 e nota 151. 
V - Conclusão

Ao final desta despretensiosa pesquisa, esperamos ter logrado demonstrar, em rápidos bosquejos, algumas das características mais interessantes do casamento romano para o jurista de hoje. Percebemos que, não-obstante as significativas diferenças existentes entre a estrutura familiar romana e aquela de nossos dias (o que é resultado evidente dos mais de vinte séculos que distanciam a nossa sociedade da da Roma antiga), muitos pontos de contato ou semelhanças podem ser encontrados.

Certamente não se pode perder de vista que toda comparação do Direito moderno com o Direito Romano no campo do Direito de Família deve ser feito com prudência, pelos motivos já explicados na introdução, e tendo em vista que qualquer semelhança não pode ser creditada a uma continuidade histórica, que aqui não existe. Entretanto, acompanhando a lúcida ponderação de Theo Mayer-Maly, ${ }^{44}$ não é apenas pela recepção de institutos jurídicos que o Direito moderno deve preitos ao Direito Romano. Pois também na esfera do Direito a história sempre se repete, e parece que os problemas com que o homem moderno hoje depara são muito freqüentemente os mesmos que os antigos quirites tiveram que enfrentar há dois mil anos, embora situados num contexto social e econômico bem diverso. $E$ o "repertório" de soluções que os juristas ontem e hoje encontram para esses problemas dá a impressão de ser bastante restrito, dado que, mutatis mutandis, os juristas modernos acabam muitas vezes chegando a resoluções análogas ou muito próximas às que os romanos já haviam formulado, mesmo quando não se trate de institutos recebidos do Direito Romano (comparemos, apenas como exemplo, fiducia cum creditore com a nossa alienação fiduciária em garantia). De resto, a influência do gênio romano é tão-marcante em nossa ciência jurídica, e o próprio modo de pensar herdado da ciência romanística tão-arraigado em nossa cultura, que é impossível deixar de lado o Direito Romano, seja qual for o campo do direito em que se queira pesquisar. Os velhos jurisconsultos ainda têm muito a nos ensinar.

São Paulo, junho de 1998.

44. "Die Wiederkehr von Rechtsfiguren", na Juristenzeitung (JZ) 1971, pp. I e ss. 